\title{
An Analysis of the Establishment and Enforcement of Anti-Market Abuse Preventative Measures in the United Kingdom
}

\author{
Howard Chitimira
}

\author{
LLB LLM LLD \\ Lecturer, Faculty of Law, North-West University \\ Email:Howard.Chitimira@nwu.ac.za/tafarachitimira@gmail.com
}

\section{Doi:10.5901/mjss.2014.v5n20p529}

\section{Abstract}

The United Kingdom has to date successfully developed and/or adopted various measures aimed at discouraging market abuse practices in its financial markets. Consequently, the preventative measures employed in the United Kingdom will be investigated and, where necessary, contrasted with similar anti-market abuse measures in South Africa. Accordingly, only relevant United Kingdom market abuse provisions and cases will be discussed and contrasted with similar provisions and cases in South Africa for the purposes of identifying market abuse preventative methods that could possibly be incorporated in the South African anti-market abuse enforcement framework. Given this background, the co-operation between the Financial Services Authority, the Treasury, the Department of Trade and Industry and the courts will be examined first. Secondly, the cooperation between the Financial Services Authority and the local self-regulatory organisations will be discussed. Thirdly, the cooperation between the Financial Services Authority and similar international regulatory bodies will be scrutinised. Fourthly, other preventative measures that were adopted in the United Kingdom will be analysed. Lastly, possible recommendations and conclusions will be given.

Keywords: market abuse, United Kingdom, preventative measures, South Africa, co-operation.

\section{Introduction}

The United Kingdom (the UK) has to date successfully developed and/or adopted various measures aimed at discouraging market abuse ${ }^{1}$ practices in its financial markets. ${ }^{2}$ Consequently, the preventative measures employed in the $\mathrm{UK}^{3}$ will be investigated and, where necessary, contrasted with similar anti-market abuse measures in South Africa. ${ }^{4}$ Accordingly, only relevant UK market abuse provisions and cases will be discussed and contrasted with similar provisions and cases in South Africa for the purposes of identifying market abuse preventative methods that could be possibly incorporated in the South African anti-market abuse enforcement framework. ${ }^{5}$ Given this background, the co-operation

\footnotetext{
${ }^{1}$ Refers to both insider trading and market manipulation in this article.

${ }^{2}$ See the Criminal Justice Act 1993 (c 36), hereinafter referred to as the Criminal Justice Act \& the Financial Services and Markets Act 2000 (c 8), hereinafter referred to as the Financial Services and Markets Act. See further Steinberg "Insider Trading Regulation-A Comparative Perspective" 2003 The International Lawyer 153 154-171; Avgouleas The Mechanics and Regulation of Market Abuse: A Legal and Economic Analysis (2005) 307; 75-502; Bhattacharya \& Daouk "The World Price of Insider Trading" 2002 Journal of Finance 75 75-108; Lyon \& Du Plessis The Law of Insider Trading in Australia (2005) 159-168, for further related comparative analysis in other jurisdictions. ${ }^{3}$ Generally see Barnes Stock Market Efficiency, Insider Dealing and Market Abuse (2009) 125.

${ }^{4}$ See ss 78; 80; 81 \& 82 of the Financial Markets Act 19 of 2012, hereinafter referred to as the Financial Markets Act; also see related discussion by Chitimira A Comparative Analysis of the Enforcement of Market Abuse Provisions (2012) LLD thesis, Nelson Mandela Metropolitan University, 332-353.

5 In relation to this, see the historical and comparative analysis of the enforcement of the market abuse ban in South Africa by Loubser "Insider Trading and other Market Abuses (Including the Effective Management of Price-sensitive Information)" in the Insider Trading Booklet final draft, (2006) 18-20; 24-27 <http://www.jse.co.za/public/insider/JSEbooklet.pdF (accessed 03-03-2014); the Johannesburg Stock Exchange Limited (the JSE) "Insider Trading and other Market Abuses (Including the Effective Management of Price-sensitive Information)" in the Insider Trading Booklet, (2013) 1-26 <http://www.jse.co.za/Libraries/JSE_Regulatory_Environment_Insider_Trading/InsiderTrading_Booklet.sflb.ashx> (accessed 03-03-2014);Van Deventer "Anti-Market Abuse Legislation in South Africa" (10-06-2008) 1-5 <http://www.fsb.co.za/public/marketabuse/ FSBReport.pdf> (accessed 05-05-2013); Myburgh \& Davis "The Impact of South Africa's Insider Trading Regime: A Report for the Financial Services Board" (25-03-2004) 8-33 <http://www.genesis-analytics.com/public/FSBReport.pdf> (accessed 09-02-2013); Chanetsa "Insider Trading is Notoriously Hard to Prosecute" Business Report 26 April 2004; Pretorius and Another v Natal South Sea Investment Trust 19653 SA 410 (W), were the courts failed to convict the suspected insider trading offenders; Blincoe "Datatec Directors Pay Up on Insider Trading Charges" (2001) <http://www.theregister.co.uk/2001/05/23/datatec_directors_pay_up/> (accessed 03-03-2014), where two Datatec directors, Jens Montanana and Robin Rindel were reportedly fined about R1 million each for insider trading by the Financial Services Board (the FSB); Barron "Greg Draws a Blank in Belfort Parallel" (2014) <http://www.timeslive.co.za/ Feeds/2014/02/02/greg-draws-a-blank-in-belfort-parallel> (accessed 03-03-2014), where Greg Blank was reportedly sentenced to eight years imprisonment for stock market-related fraud and front running in 1992; Osode "The new South African Insider Trading Act: Sound law reform or legislative overkill?" 2000 Journal of African Law 239 239-263; Jooste "A critique of the insider trading provisions of the 2004 Securities Services Act" 2006 SALJ 437 441-460; Van Deventer "New watchdog for insider trading" 1999 FSB Bulletin 2 3; Beuthin \& Luiz Beuthin's Basic Company Law (2000) 235-238; Luiz "Market Abuse and the Enforcement Committee" 2011 SA Merc LJ 151-172; Luiz "Insider Trading Regulation - If at First You Don't Succeed..." 1999 SA Merc LJ 136 136-151; Henning \& Du Toit "The Regulation of False Trading, Market Manipulation and Insider Trading" 2000 Journal for Juridical Science 155 155-165; Botha "Control of Insider Trading in South Africa: A Comparative Analysis" 1991 SA Merc LJ 1 1-18; Botha "Increased Maximum Fine for Insider Trading: A Realistic and Effective Deterrent?" 1990 SALJ 504-508 \& Chitimira The Regulation of Insider Trading in South Africa: A Roadmap for an Effective, Competitive and Adequate Regulatory Statutory Framework (2008) LLM dissertation, University of Fort Hare, 1-175.
} 
between the Financial Services Authority (the FSA), the Treasury, the Department of Trade and Industry (the DTI) and the courts will be examined first. Secondly, the co-operation between the FSA and the local self-regulatory organisations (the SROs) will be discussed. Thirdly, the co-operation between the FSA and similar international regulatory bodies will be scrutinised. Fourthly, other preventative measures that were adopted in the UK will be analysed. Lastly, possible recommendations and conclusions will be given.

\section{Co-operation between Enforcement Authorities}

\subsection{Co-operation between the FSA, the Treasury, the DTI and the Courts}

A number of notable achievements obtained by the market abuse regime in the UK have been largely influenced by a good co-operative relationship that existed between the FSA and other enforcement authorities like the Treasury, the courts and the DTI. Accordingly, this sub-heading will investigate whether such co-operative effort is still being employed by the FSA to curb market abuse activities in the UK.

Firstly, the Treasury entered into an agreement with the FSA in October 1997 which outlines, among other aspects, the terms of their relationship and guiding principles on accountability, transparency and regular information exchange. ${ }^{6}$ This agreement was introduced to enhance the efficiency and effectiveness of the securities and financial services industry regulation in the UK. In addition, the same agreement improved the FSA's monitoring and supervision of the clearing and settlements systems, relevant financial markets, and companies in order to detect and discourage market abuse violations. The aforementioned agreement has further enabled the FSA to formulate adequate policy and principles regarding its general regulatory functions.

Secondly, the FSA and the DTI had concurrent jurisdiction to investigate and prosecute certain matters involving serious corporate frauds and market abuse offences. ${ }^{7}$ For example, it is reported that the DTI could appoint its own investigators and inspectors to deal with any specific or suspected securities violations. ${ }^{8}$ The DTI could further disclose certain information to the FSA and other relevant enforcement authorities for them to take any appropriate action. ${ }^{9}$ This could imply, notwithstanding the fact that some of the DTI's market abuse prosecutorial powers are now vested in the Department for Business Enterprise and Regulatory Reform (the DBERR), that there was a better co-operation relationship between the DTI and the FSA in relation to the enforcement of securities and market abuse laws in the UK. It is hoped that such co-operation relationship will also be carried out between the DBERR and the FSA.

Lastly, the relevant courts ${ }^{10}$ are mostly responsible for the criminal enforcement of the market abuse prohibition in the UK. In practice, the courts may, nevertheless, prosecute any market abuse cases referred to them by the FSA. As a result, the courts and the FSA have to date achieved some substantial progress in their quest to eradicate market abuse practices in the relevant financial markets in the UK. Furthermore, the courts have on many occasions relied on the help of the Crown Prosecution Services (the CPS) and the FSA to obtain a number of settlements and convictions in market abuse cases. ${ }^{11}$ For example, in Chase Manhattan Equities $v$ Goodman ${ }^{12}$ Knox $\mathrm{J}$ held that the accused persons were guilty of misusing material non-public inside information. The court further held that the illicit trading of these accused persons was tantamount to an offence against public policy. Moreover, in Seager v Copydex (No 2), ${ }^{13}$ damages were awarded against the person who misused confidential non-public inside information (insider trading) for personal gain.

The effectiveness of the co-operation between the FSA and the courts was further revealed in Financial Services Authority $v$ Rourke, ${ }^{14}$ where Neuberger $\mathrm{J}$ imposed a declaratory injunctive relief against the accused persons who violated the Financial Services and Markets Act's provisions on the disclosure of confidential information. ${ }^{15}$ The courts of Appeal have to date been able to assist the FSA to make appropriate decisions in relation to any appeal raised by the aggrieved persons. Significant efforts have also been successfully made by both the courts and the FSA to curb crossborder market abuse activities. For example, the FSA may appoint specific competent persons and assign them to assist the courts to investigate and/or prosecute market abuse violations perpetrated in the UK by persons domiciled

\footnotetext{
${ }^{6}$ See Blair \& Walker Financial Services Law (2006) 35.

${ }^{7}$ Blair \& Walker Financial Services Law 299-300.

${ }^{8}$ Blair \& Walker Financial Services Law 299-300.

${ }^{9}$ Blair \& Walker Financial Services Law 299.

${ }^{10}$ These include the High Courts, Supreme Courts and the Courts of Appeal.

${ }^{11}$ Blair \& Walker Financial Services Law 300.

12[1991] BCLC 897.

${ }^{13}$ [1969] 1 WLR 809.

${ }^{14}(H C, 2001-10-19)$

15S 348. Also see Russen Financial Services Authorisation, Supervision (2006)148-149.
} 
elsewhere. ${ }^{16}$

On the other hand, as is the position with the FSA, ${ }^{17}$ the FSB has to date received considerable help, especially in respect of the criminal prosecution of market abuse cases, from the courts and the Director of Public Prosecutions (the DPP) in South Africa. ${ }^{18}$ As has already been discussed above, ${ }^{19}$ the DPP in South Africa, like the CPS of the UK, ${ }^{20}$ usually prosecutes matters relating to market abuse after a referral from the FSB or other relevant authorities. This could, in a way, suggest that the DPP in South Africa may only commence its own investigations or prosecution of market abuse offences after consultation with the FSB. ${ }^{21}$ As indicated above, although it may be prima facie presumed that the FSB supports the DPP and the relevant courts with the necessary information regarding ongoing market abuse cases in South Africa, it is not clear whether the FSB is statutorily mandated to assign certain persons with the relevant expertise to assist the courts in their prosecution of such cases. ${ }^{22}$ Moreover, notwithstanding the outstanding effort that is being made by the courts and the FSB to prosecute market abuse cases timeously and effectively, the paucity of successful settlements or prosecutions that have been obtained in such cases remains a major challenge in South Africa to date. ${ }^{23}$ Relatively few settlements have been obtained in cases involving market abuse activities like market manipulation in South Africa. ${ }^{24}$ In line with this, it remains to be seen whether the co-operation relationship between the FSB, the courts and the DPP will give rise to more convictions and settlements in matters involving market abuse in South Africa. ${ }^{25}$ Additionally, as similarly stated above, it is uncertain whether the courts and the FSB have been successful with regard to the combating of cross-border market abuse practices. ${ }^{26}$ For example, no single case involving cross-border market abuse activities has been reported or successfully prosecuted in South Africa to date. ${ }^{27}$ Accordingly, this raises some doubt as to whether the co-operative efforts of the courts and the FSB have to date sufficiently and effectively dealt with the market abuse violations in South Africa and elsewhere.

\subsection{Co-operation between the FSA and the Local SROs}

As indicated earlier, ${ }^{28}$ the FSA does not work in isolation. It involves SROs such as the London Stock Exchange (the LSE), the London International Financial Futures and Options Exchange Administration and Management (the LIFFOEAM), the Serious Fraud Office (the SFO), the Financial Services and Markets Tribunal (the FSMT), the Financial Ombudsman Service (the FOS) and the Regulatory Decisions Committee (the RDC) in order to enhance its anti-market abuse enforcement efforts. Consequently, this sub-heading will scrutinise whether this co-operative enforcement approach has managed to reduce market abuse practices in the UK. A brief analysis of the functions of the FSA and selected SROs in relation to this co-operative approach will be therefore carried out under this sub-heading.

The FSA has entered into several operating arrangements (co-operation agreements) with certain SROs which are directly or indirectly involved in the enforcement of market abuse laws in the UK. For instance, the FSA and the LSE have stipulated relevant guidelines which help them to determine the appropriate action that will be taken by either the LSE or the FSA with regard to suspected market abuse cases in order to avoid unnecessary duplication of their functions. Moreover, both the FSA and the LSE employ the same computerised surveillance systems to detect and prevent market abuse practices in the UK's financial markets. This has enabled the FSA to investigate and prosecute market abuse violations that are committed over the Internet in respect of any prescribed financial markets in many instances. ${ }^{29}$ Similarly, the FSA has forged some good co-operation agreements with the LIFFOEAM to detect, investigate and prosecute all market abuse cases relating to any qualifying investments that are dealt with on the LIFFOEAM or other prescribed financial markets. ${ }^{30}$ Thus, the FSA, with the help of the LIFFOEAM, may detect and track any suspected

\footnotetext{
${ }^{16}$ Also see further Blair \& Walker Financial Services Law 34-38 \& 302-303 \& Rider, Alexander, Linklater \& Bazley Market Abuse and Insider Dealing (2009) $190-195$.

17 See related remarks above.

${ }_{18}$ See related analysis by Chitimira \& Lawack "Overview of the Role-Players in the Investigation, Prevention and Enforcement of Market Abuse Provisions in South Africa" 2013 Obiter 200 200-217; Chitimira "Overview of Selected Role-Players in the Detection and Enforcement of Market Abuse Cases and Appeals in South Africa" 2014 Speculum Juris 108 108124.

${ }^{19}$ See Chitimira \& Lawack 2013 Obiter 200-217; Chitimira 2014 Speculum Juris 108-124.

20 See related remarks above.

${ }^{21} \mathrm{~S} 84(10)$ of the Financial Markets Act.

${ }^{22}$ Generally see Chitimira \& Lawack 2013 Obiter 200-217; Chitimira 2014 Speculum Juris 108-124.

${ }^{23}$ See similar analysis by Chitimira \& Lawack 2013 Obiter 200-217; Chitimira 2014 Speculum Juris 108-124.

${ }^{24}$ See Pretorius v Natal South Sea Investment Trust Limited 410, where the court held that the accused persons were guilty for prejudicing other investors by selling overpriced securities (market manipulation).

${ }^{25}$ Unlike in the UK, there is no person who has been convicted for insider trading in South Africa. See related analysis by Chitimira \& Lawack 2013 Obiter $200-217$; Chitimira 2014 Speculum Juris 108-124.

${ }^{26}$ See related analysis by Chitimira \& Lawack 2013 Obiter 200-217; Chitimira 2014 Speculum Juris 108-124.

${ }^{27}$ See related analysis by Chitimira \& Lawack 2013 Obiter 200-217; Chitimira 2014 Speculum Juris 108-124.

${ }^{28}$ See similar discussion in paragraph 2.1 above.

${ }^{29}$ See Blair \& Walker Financial Services Law 301-303, for generally related remarks.

${ }^{30}$ S 118(5) of the Financial Services and Markets Act. Also see Rider, Alexander, Linklater \& Bazley Market Abuse and Insider Dealing 73-74.
} 
market abuse activity in the prescribed financial markets situated in the UK or which are accessible electronically in the UK or in any member state of the European Union (the EU). ${ }^{31}$

Furthermore, the SFO and the FSA are both responsible for investigating and curbing serious fraud and other illicit trading practices that amount to market abuse in the UK. This has nonetheless resulted in the duplication of some of the regulatory functions by either the FSA or the SFO, especially with regard to market abuse violations. ${ }^{32}$ One can therefore assume that this overlap of functions that usually occurs between the SFO and the FSA could be indication of an inconsistent co-operative enforcement relationship between these two regulatory bodies. Be that as it may, the FSA is mainly responsible for policing the market abuse prohibition in the UK. In view of this, the SFO may only prosecute certain market abuse cases if it reasonably believes that such cases also constitute serious fraud. ${ }^{33}$ Where such market abuse violations are detected and investigated by the SFO, they may be referred to the CPS or the FSA for further prosecution. ${ }^{34}$

The FOS and the FSA have been co-operatively involved to curb market abuse activities in the UK. For instance, the FOS hears individual disputes involving cases of market abuse that do not necessarily fall under the ambit of the FSA. ${ }^{35}$ In so doing, the FOS enables the FSA to resolve any outstanding matters involving market abuse cases in order to promote the efficiency and integrity of the UK's financial markets. Put differently, the FSA has put in place some guidelines that govern and allow the FOS to take independent and appropriate action regarding complaints against any decision of the FSA or other relevant enforcement authorities. ${ }^{36}$ The FSA has permitted the FOS to administer independent claims under the Financial Services Compensation Scheme in order to afford all the aggrieved persons an opportunity to obtain adequate redress. ${ }^{37}$

Additionally, the FSMT offers a platform for prejudiced persons to appeal against the decisions of the FSA. In other words, the FSMT and the FSA have some co-operation guidelines in place to enable them to perform their functions more effectively. These guidelines further allow the FSMT to advise the FSA regarding its disputed decisions or any other relevant matter. ${ }^{38}$ The FSA has further exploited its mutual co-operation with the RDC to investigate and prosecute market abuse violations in the UK.

The RDC is responsible and accountable to the FSA for its decisions in relation to market abuse cases. This could prima facie imply that there is a good co-operation relationship between the FSA and the RDC, especially with regard to the enforcement of market abuse laws in the UK. ${ }^{39}$

In addition, as indicated above and as is the position in the UK, ${ }^{40}$ the FSB works hand in hand with other local SROs to complement its anti-market abuse enforcement efforts. ${ }^{41}$ Like the LSE, ${ }^{42}$ the JSE has to date been assisting the FSB with the surveillance, detection and investigation of suspicious illicit activities which in most instances would be indicative of market abuse violations. ${ }^{43}$ This shows that there is some co-operation and relevant information sharing between the FSB and the JSE. ${ }^{44}$ Moreover, the JSE has now consolidated the functions of the Bond Exchange of South Africa in order to investigate and curb commodities-based market abuse practices in South Africa. This suggests that the FSB now relies on the JSE to detect and combat commodities-based market abuse practices in the South African financial markets. ${ }^{45}$ Nevertheless, the fact still remains that a relatively few market abuse cases reported to the FSB by either the JSE or other enforcement authorities have to date been successfully settled and prosecuted in South Africa under the Financial Markets Act. ${ }^{46}$ This status quo is likely to continue because the Financial Markets Act does not

\footnotetext{
${ }^{31}$ This has enabled the FSA to discourage and combat cross-border market abuse practices. Also see Rider, Alexander, Linklater \& Bazley Market Abuse and Insider Dealing 74.

${ }^{32}$ Blair \& Walker Financial Services Law 300.

${ }^{33}$ Blair \& Walker Financial Services Law 300.

${ }^{34}$ The FSA signed co-operation agreements with the Association of Chief Police Officers of England and Wales to enhance its investigation and prosecution of market abuse practices in the UK. See further Russen Financial Services Authorisation, Supervision 96.

${ }^{35}$ See further related analysis above.

${ }^{36}$ See generally ss 226 \& 227 read with ss 155 \& 225 of the Financial Services and Markets Act: also see Avgouleas The Mechanics and Regulation of Market Abuse $409-411$.

${ }^{37}$ See $R$ (on the application of Davies and others) v Financial Services Authority [2003] 4 All ER 1196 where the applicants sought a judicial review to challenge the decision of the FSA to issue a warning notice pursuant to $s 6$ of the Financial Services and Markets Act without initially referring the matter to the FSMT.

${ }^{38}$ For example, in Legal and General Assurance Society Limited v Financial Services Authority (2005) FSMT 016 the FSMT upheld a decision made by the FSA to award a public censure and a financial penalty against the applicants and warned the FSA to be flexible in order to give appropriate penalties in such matters in the future; also see Piggott v FSA (2003) FSMT 004 the FSMT reduced the financial penalty imposed by the FSA from $£ 40000$ to $£ 10000$ citing that the applicants were having some difficulties in paying the initial penalty and see further Mohammed v FSA (2005) 013 the FSMT held that the applicant's other share dealings were not in themselves unlawful and were therefore not in contravention of $s 118$ of the Financial Services and Markets Act. Also see generally Russen Financial Services Authorisation, Supervision 194-195; Avgouleas The Mechanics and Regulation of Market Abuse 382-383.

${ }^{39}$ Swan Market Abuse Regulation (2006) 106-107.

40 See related remarks above.

41 See related remarks above.

42 See earlier comments above.

${ }^{43}$ See related discussion by Chitimira \& Lawack 2013 Obiter 200-217; Chitimira 2014 Speculum Juris 108-124.

44 See further analysis by Chitimira \& Lawack 2013 Obiter 200-217; Chitimira 2014 Speculum Juris 108-124.

${ }^{45}$ See further analysis by Chitimira \& Lawack 2013 Obiter 200-217; Chitimira 2014 Speculum Juris 108-124.

${ }^{46}$ See relevant provisions under Chapter X of the Financial Markets Act; also see related analysis by Chitimira \& Lawack 2013 Obiter 200-217; Chitimira 2014 Speculum Juris 108124.
} 
expressly and statutorily impose a mandatory co-operation obligation on both the FSB and the JSE to improve the enforcement of the market abuse prohibition in South Africa. ${ }^{47}$

The Directorate of Market Abuse (the DMA) has similar roles as those of the RDC and it investigates and exercises some functions on behalf of the FSB. ${ }^{48}$ Currently, the FSB and the DMA work closely and consult each other in relation to the making of market abuse rules, penalties and any other decisions. ${ }^{49} \mathrm{It}$ is hoped that this co-operation between the FSB and the DMA will in future produce more settlements and convictions, especially in criminal cases of market abuse..$^{50}$ Notwithstanding the fact that the FSB and the DMA convene regular meetings to discuss and share any relevant confidential information, especially in respect of ongoing market abuse investigations, more may still need to be done to increase the number of market abuse cases that are successfully prosecuted and/or settled in South Africa.

Likewise, the Takeover Regulation Panel (the TRP) offers additional support to the FSB in relation to the regulation and enforcement of securities laws in South Africa. ${ }^{51}$ For example, the TRP has some requirements in place pertaining to the disclosure of price-sensitive information. ${ }^{52}$ This is aimed at preventing insider trading and market manipulation by insiders in relation to the offeror or offeree company by dealing unlawfully in securities of the affected companies at an early stage of the negotiations. All parties to an offer relating to an affected transaction are required to take reasonable steps to prevent the making or publication of misleading statements, creation of false markets and other market abuse activities. ${ }^{53}$ However, the extent of co-operation between the FSB and the TRP remains unclear. It appears as if the TRP does not involve itself much in the day-to-day enforcement of matters relating to market abuse as such matters usually concern the FSB. Consequently, the actual degree of co-operation between the FSB and the TRP is very difficult to ascertain since the TRP does not primarily deal with the enforcement of the market abuse prohibition in South Africa on a more regular basis.

Furthermore, like the FSMT of the UK, ${ }^{54}$ the Enforcement Committee (the EC) ${ }^{55}$ provides all aggrieved persons with an opportunity to appeal against any decisions of the FSB, especially with regard to the penalties for market abuse. ${ }^{56}$ While this is important in that it helps the FSB to review its own decisions and to make appropriate decisions in relation to its market abuse enforcement and regulatory functions, only a minimum number of market abuse cases have been settled with the EC to date..$^{57}$ Accordingly, this could be an indication that there is inconsistent, little or no co-operation between the FSB and the EC.

\subsection{Co-operation between the FSA and Similar International Regulatory Bodies}

The FSA entered into some co-operation agreements (Memoranda of Understanding) with several regulatory bodies in other jurisdictions. For example, the FSA signed a separate Memorandum of Understanding (the MOU) with the United States Securities and Exchange Commission (the SEC) and the Commodity Futures Trading Commission (the CFTC) in October $1997 . .^{58}$ The main objective of this MOU is inter alia to improve the ability of the bodies concerned to exchange relevant information in respect of the activities, internal controls and management systems of the UK and the United States of America (the US)'s companies that operate internationally. ${ }^{59} \mathrm{In}$ addition, this MOU developed procedures to increase co-operation, especially in connection with important market events occurring in the UK and the US's banking companies, securities and financial markets. ${ }^{60}$

Furthermore, the FSA forged bilateral and multilateral MOU with leading international regulatory bodies such as the Basel Committee on Banking Supervision (the BCBS), the Financial Action Task Force (the FATF), the Joint Forum on Financial Conglomerates, ${ }^{61}$ the International Organisation of Securities Commissions (the IOSCO), the Financial Stability

\footnotetext{
${ }^{47}$ See relevant provisions under Chapter X of the Financial Markets Act; also see related analysis by Chitimira \& Lawack 2013 Obiter 200-217; Chitimira 2014 Speculum Juris 108124.

${ }^{48} \mathrm{~S} 85$ of the Financial Markets Act.

${ }^{49}$ See s 84(2)(f) read with $s 85$ of the Financial Markets Act.

${ }^{50}$ See similar analysis See relevant provisions under Chapter X of the Financial Markets Act; also see related analysis by Chitimira \& Lawack 2013 Obiter $200-217$; Chitimira 2014 Speculum Juris 108-124.

${ }^{51}$ See related analysis by Chitimira 2014 Speculum Juris 108-124.

${ }^{52}$ See related analysis by Chitimira 2014 Speculum Juris 108-124.

${ }^{53}$ See the TRP Rules and/or General Principles; notably, the TRP was formerly called the Securities Regulation Panel (the SRP), see especially the SRP General Principles 6 \& 9.

${ }^{54}$ See earlier remarks above.

${ }^{55}$ See ss 85 \& 99 of the Financial Markets Act; ss 6A to 61 of the Financial Institutions (Protection of Funds) Act 28 of 2001 as amended, hereinafter referred to as the Protection of Funds Act .

${ }^{56}$ See related remarks by Chitimira \& Lawack 2013 Obiter 200-217; Chitimira 2014 Speculum Juris 108-124.

${ }^{57}$ Generally see similar remarks by Chitimira \& Lawack 2013 Obiter 200-217; Chitimira 2014 Speculum Juris 108-124.

${ }^{58}$ See Blair \& Walker Financial Services Law 37.

${ }^{59}$ Generally see Blair \& Walker Financial Services Law 37.

${ }^{60}$ Additionally, this MOU has generally improved the relations between the FSA, the CFTC \& the SEC as well as the effectiveness of the financial supervision in discouraging crossborder market abuse activities in both the UK and the US's financial markets.

${ }^{61}$ This body is now known as the Joint Forum.
} 
Forum, and the Committee on the Global Financial System. ${ }^{62}$ The FSA also entered into other short term co-operation arrangements known as the Financial Information Sharing Agreements with SROs and regulators in other jurisdictions in order to share information that will be relevant to any ongoing investigations of securities and/or market abuse violations. ${ }^{63}$ The FSA is a member of the IOSCO. This membership enables the FSA to exchange relevant information with other regulatory bodies that are also members of the IOSCO.64 It further empowers the FSA to co-operate with similar regulatory bodies elsewhere in order to establish good corporate standards and better surveillance systems to combat cross-border market abuse practices. ${ }^{65}$ In addition, the FSA specifically signed the IOSCO Multilateral Memorandum Concerning Consultation, Cooperation and the Exchange of Information. ${ }^{66}$ This MOU allows the FSA to obtain mutual assistance from other international regulatory bodies and to adopt better corporate standards that will enhance the enforcement and prosecution of cross-border market abuse offences. ${ }^{67}$ The UK co-chaired the IOSCO taskforce on unregulated financial entities with Italy. This enabled the FSA to focus closely on unregulated entities and hedge funds in order to devise alternative regulatory approaches that curb the negative effects associated with their trading and global opacity. ${ }^{68}$

The FSA co-operates with similar regulatory bodies in the EU member countries. As envisaged in the EU Market Abuse Directive, the FSA may track and prosecute market abuse activities conducted in the UK in relation to qualifying investments listed on a regulated financial market in any other EU member state. ${ }^{69}$

Likewise, the FSA has reportedly received assistance from other affiliate bodies such as the BCBS, the Joint Forum, the FATF and the Organisation for Economic Co-operation and Development (the OECD) to develop principles and/or identify practices that will reduce illicit trading activities like market abuse as much as possible. ${ }^{70}$ This has also enabled the FSA to improve its supervisory methods and market abuse enforcement approaches. ${ }^{71}$

In contrast to the FSA, ${ }^{72}$ it is not certain whether the FSB has also entered into some co-operation arrangements with international regulatory bodies that deal with commodities-based market abuse practices such as the CFTC, the LIFFOEAM and the Trade Point Stock Exchange (the TPSE). ${ }^{73}$ Likewise, it is not clear whether South Africa has also ratified any agreement with the OECD74 in order to enable the FSB to improve its policies regarding the monitoring, investigation, information gathering and the adoption of other appropriate market abuse enforcement approaches. Nevertheless, the FSB should be commended for its great efforts to respond to the mounting global concern over the negative effects of market abuse activities. ${ }^{75}$ It has, for instance, joined the IOSCO in order to learn from the experiences of similar regulatory bodies that are members of the IOSCO. ${ }^{76}$ For example, in light of this, the FSB can rely on its IOSCO membership to co-operate with other regulators such as the Securities and Exchange Board of India (the SEBI) to track and investigate market abuse activities that relate to the affected securities in South Africa by the perpetrators who anonymously dealt in such securities while in India. ${ }^{77}$ However, it is unclear whether the FSB has concluded any binding co-operation MOU with the SEBI in relation to the enforcement of the cross-border market abuse prohibitions.

\section{The Adoption of Adequate Preventative Measures}

The UK, like many other countries, has developed and adopted several methods to prevent market abuse practices in all its prescribed financial markets. These methods include providing a definition of, and enumerating the conduct that amounts to market abuse, reliance on criminal, civil and administrative penalties, public censure and the use of surveillance systems.

For example, a wide but comprehensive definition of practices that constitute market manipulation and other

\footnotetext{
${ }^{62}$ See Blair \& Walker Financial Services Law 34-38.

${ }^{63}$ See generally Blair \& Walker Financial Services Law 37.

${ }^{64}$ See generally Blair \& Walker Financial Services Law 37-38.

${ }^{65}$ See generally Blair \& Walker Financial Services Law 37-38.

${ }^{66}$ Blair \& Walker Financial Services Law 37-38 \& 826-830.

67 See further Blair \& Walker Financial Services Law 826-830; Rider, Alexander, Linklater \& Bazley Market Abuse and Insider Dealing 271-275.

${ }^{68}$ See similar discussion by Blair \& Walker Financial Services Law 826-830; Rider, Alexander, Linklater \& Bazley Market Abuse and Insider Dealing 271-275.

${ }^{69} \mathrm{Also}$ see Article 16(1) of the European Union Directive on Insider Dealing and Market Manipulation, the Directive of the European Parliament and Council of 28 January 2003 on insider dealing and market manipulation (market abuse) 2003/6/EC [2003] OJ L96/16, hereinafter referred to as the EU Market Abuse Directive, which provides some guiding principles which allow regulatory bodies in the EU member countries to co-operate whenever necessary for the purpose of effectively executing their duties, especially with regard to market abuse enforcement. Also see Blair \& Walker Financial Services Law 302-303.

70 See generally Blair \& Walker Financial Services Law 34-35 \& 830-836.

${ }^{71}$ See generally Blair \& Walker Financial Services Law 34-35 \& 830-836.

72 See related analysis above.

73 This might further suggest that commodities-based cross-border market abuse practices are not being sufficiently detected and prosecuted in South Africa.

${ }^{74}$ Blair \& Walker Financial Services Law (2006) 832-833.

${ }^{75}$ See similar remarks by Chitimira \& Lawack 2013 Obiter 200-217; Chitimira 2014 Speculum Juris 108-124.

${ }^{76}$ Generally see related comments by Chitimira \& Lawack 2013 Obiter 200-217; Chitimira 2014 Speculum Juris 108-124.

${ }^{77}$ Also see similar comments by Chitimira \& Lawack 2013 Obiter 200-217; Chitimira 2014 Speculum Juris 108-124.
} 
related market abuse offences is statutorily provided for in the UK. Specifically, about seven types of conduct that amount to or that could give rise to market abuse are clearly stipulated in the Financial Services and Markets Act. ${ }^{78}$ The UK's market abuse regime further discourages and prohibits Internet-based market manipulation practices. ${ }^{79}$ This has led to a substantial increase in compliance and enforcement of the market abuse laws in the UK to date.

The UK's market abuse regime also employs appropriate penalties to discourage all persons from committing market abuse offences. For example, criminal penalties may be levied against the offenders under both the Financial Services and Markets Act and the Criminal Justice Act. ${ }^{80}$ Notably, criminal penalties under the Criminal Justice Act are only limited to individuals who commit insider trading and very few convictions have been obtained in such cases so far. The Financial Services and Markets Act has, however, now extended this criminal liability to both individuals and companies. ${ }^{81}$ Moreover, offenders may incur civil and administrative penalties for market abuse under the Financial Services and Markets Act. Therefore, the FSA may impose unlimited financial penalties on companies or individuals who indulge in market abuse practices. ${ }^{82}$ The UK's market abuse regime also provides separate and different penalties for individuals and companies. This has arguably increased deterrence on the part of the offenders and improved the overall enforcement of the market abuse prohibition in the UK.83

Apart from relying on penalties, the FSA may further issue public statements to the effect that the accused person was involved in market abuse in some instances where it reasonably believes that issuing such statements is the more appropriate sanction. ${ }^{84}$ These public statements are also employed in instances where the accused persons have taken responsibility of their market abuse conduct as well as reasonable steps to co-operate with the FSA and where such persons are unable to pay the imposed financial penalty. ${ }^{85}$ This name and shame approach is usually employed to deter and prevent unscrupulous persons from wilfully indulging in market abuse activities in the UK's prescribed financial markets. 86

The FSA also relies on the LSE's surveillance systems to detect possible market abuse activities in the UK's prescribed financial markets. ${ }^{87}$ Specifically, the LSE reports any cases of suspected market abuse through the Suspicious Transaction Reports (the STRs) to the FSA for further adjudication. Thus the FSA is responsible for the investigation and prosecution of market abuse practices which occur on the LSE and any other prescribed financial markets in the UK. ${ }^{88}$

Investigation and information gathering is another tool used by the FSA's Enforcement Division to combat market activities in the UK's prescribed financial markets. ${ }^{89}$ The FSA has powers to appoint specific skilled persons to investigate and submit reports pertaining to ongoing market abuse cases..$^{90}$ In addition, the FSA may summon and interrogate any persons suspected to have contravened the relevant market abuse provisions in the UK. ${ }^{91}$ The FSA also has the power to impose Anton pillar orders and to search and seize any documents or material from any person or premises if it reasonably believes that such material or documents will be essential to its market abuse investigations. In most instances, the FSA searches any person or premises after having obtained permission from the competent courts in the UK. Consequently, a number of market abuse cases have so far been successfully investigated by both the RDC ${ }^{92}$ and the FSA. ${ }^{93}$

The FSA further employs whistle-blowing immunity provisions to promote prompt disclosure (tip-offs) by all persons who are aware of any market abuse activities without fear of reprisals. Whistle-blowers in the UK are therefore protected against the risk of being victimised, losing their jobs or sidelined in their careers. This has since improved the timeous disclosure of relevant information to the prescribed financial markets through the Internet or the STRs by all the market participants in the UK. The FSA also imposes a duty on directors, employees and other relevant persons to report or

\footnotetext{
${ }^{78}$ See s 118(1) to (8).

${ }^{79}$ The making or publishing of false, deceptive or misleading statements to manipulate the financial markets over the Internet is prohibited in the UK. See generally Cassim "An Analysis of Market Manipulation under the Securities Services Act 36 of 2004 (part 2)" 2008 SA Merc LJ 177 182-183.

80 See related remarks in paragraph 1 above.

${ }^{81}$ See generally s 118(1) to (8).

$82 S$ 123(1) of the Financial Services and Markets Act.

${ }^{83}$ See generally Cassim 2008 SA Merc LJ 191-195.

${ }^{84} \mathrm{~S}$ 123(3) of the Financial Services and Markets Act; also see generally FSA's Enforcement (Manual) Handbook Release 064 April 2007 , which is hereinafter referred to simply as the "ENF", see ENF 14.4.1G.

${ }^{85}$ See ENF 14.6.2G(6).

${ }^{86}$ Generally see Cassim 2008 SA Merc LJ 195-196.

87 See related comments in paragraph 2.2 above.

88 This could further imply that the FSA is empowered to combat market abuse practices in relation to both listed and unlisted qualifying investments. A central computerised system known as the Stock Exchange Electronic Trading Service (SEETS) is usually used to detect the occurrence of such practices in the relevant financial markets in the UK.

89 See related discussion in paragraphs $2.1 ; 2.2 \& 2.3$ above.

${ }^{90}$ See related analysis in paragraphs $2.1 ; 2.2 \& 2.3$ above.

${ }^{91}$ See related discussion in paragraphs $2.1 ; 2.2 \& 2.3$ above.

${ }^{92}$ See related comments in paragraph 2.2 above.

${ }_{93}$ Wood Regulation of International Finance (The Law and Practice of International Finance Series Volume 7) (2007) 591.
} 
speedily publish non-public price-sensitive information relating to qualifying investments or their dealing in any qualifying investments in order to discourage illicit trading practices like insider trading. ${ }^{94}$

Additionally, the FSA uses awareness programmes to combat and discourage market abuse practices in the prescribed UK's financial markets. The FSA has also provided the Code of Market Conduct to guide and educate all relevant persons regarding market abuse. The FSA has, in some instances, relied on public lectures and publishing important information through the Internet to inform all the relevant stakeholders regarding any illicit trading activities. This has assisted the FSA to develop and establish a good anti-market abuse corporate ethics culture among all the market participants and issuers of qualifying investments. The FSA has formulated extensive Listing Principles which must be followed by all issuers of qualifying investments. ${ }^{95}$ These Listing Principles allow all the listed companies to take reasonable steps to train their directors about their duties, maintain adequate procedures, systems and controls which enable them to execute their functions well, and to promote market integrity. ${ }^{96}$

The UK's market abuse regime has established the FSA as the main competent regulatory body to police the enforcement of the market abuse prohibition. ${ }^{97}$ This is the so-called single regulator model and it is used in the UK as a measure to discourage and combat market abuse practices in its financial markets. Thus, although the FSA co-operates with and delegates some of its functions to other local SROs like the RDC; 98 it remains mainly responsible for the enforcement of the market abuse prohibition in the UK.

Moreover, the FSA uses transaction recording, telephonic tapping, exit interviews, staff vetting checks, review of unusual trades and regular internal audit review of polices, systems and controls of issuers to prevent market abuse activities. ${ }^{99}$ For purposes of preventing cross-border market abuse activity, the FSA usually invokes its fellow regulators in other jurisdictions to prosecute market abuse offences committed in the UK by persons in other countries. ${ }^{100}$

A private right of action in relation to certain market abuse offences is further used to discourage market abuse activities in the UK. ${ }^{101}$ Therefore, all the prejudiced persons are given an opportunity to claim their damages or compensation directly from the market abuse offenders. ${ }^{102}$ This has, in a way, afforded the affected persons an alternative arbitration method to obtain their damages speedily from the market abuse offenders. On the other hand, this private right of action method has increased deterrence on the part of the market abuse offenders to disengage from their illegal trading activities. ${ }^{103}$ Over and above, it is generally accepted that some of the persons have so far successfully relied on this private right of action to claim their damages from either the companies or the individuals who involved themselves in market abuse practices. 104

Unlike the position in the UK, ${ }^{105}$ there was no attempt on the part of the South African legislature to define the concept of market abuse comprehensively. ${ }^{106}$ In addition, unlike the position in the UK, ${ }^{107}$ the FSB is not statutorily authorised to impose unlimited financial penalties on the market abuse offenders. ${ }^{108}$ Moreover, no separate and distinct penalties for violating market abuse provisions are given to individuals and companies in South Africa. ${ }^{109}$ Nonetheless, like the situation in the UK, 110 the FSB is now statutorily empowered to issue public statements to expose the perpetrators of market abuse under the Financial Markets Act. ${ }^{111}$ However, it is not very clear whether this name and shame approach may be used by the FSB in conjunction with another penalty for market abuse deterrence purposes under the Financial

\footnotetext{
${ }^{94}$ See the FSA's Disclosure and Transparency Rules 2.6.1; 2.6.2; 2.2.8; 2.2.9; 2.8.1; 2.8.1; 2.8 .3 to 2.8.10. Also see Wood Regulation of International Finance 591; Barnes Stock Market Efficiency, Insider Dealing 119-121.

${ }^{95} \mathrm{Also}$ see further the FSA's Disclosure and Transparency Rules 2.6.1; 2.6.2; 2.2.8; 2.2.9; 2.8.1; 2.8.1; 2.8.3 to 2.8.10. Also see Wood Regulation of International Finance 591; Barnes Stock Market Efficiency, Insider Dealing 119-121.

96 Generally see further the FSA's Disclosure and Transparency Rules 2.6.1; 2.6.2; 2.2.8; 2.2.9; 2.8.1; 2.8.1; 2.8 .3 to 2.8.10. Also see Wood Regulation of International Finance 591; Barnes Stock Market Efficiency, Insider Dealing 119-121.

${ }_{97}$ See related discussion in paragraphs $2.1 ; 2.2$ \& 2.3 above.

${ }^{98}$ See the discussion in paragraph 2.2 above.

${ }^{99}$ Barnes Stock Market Efficiency, Insider Dealing 122-123.

100 See the discussion in paragraph 2.3 above.

${ }^{101}$ See ss 150; 380 \& 382 of the Financial Services and Markets Act. Notably, the court orders for a private right of action do not apply to market abuse violations regarding s 397 of the Financial Services and Markets Act.

102 See ss 150; 380 \& 382 of the Financial Services and Markets Act.

103 See Rider, Alexander, Linklater \& Bazley Market Abuse and Insider Dealing 94.

${ }^{104}$ See Barnes Stock Market Efficiency, Insider Dealing 164-175; also see In Re A-G's Reference (No 1 of 1998) [1998] BCLC 193, where Lord Lane CJ ruled in favour of a plaintiff who was prejudiced by any insider (offender) who had dealt dishonestly in respect of the affected securities concerned \& In Re A-G's Reference (No 1 of 1988) [1989] AC 971 973$977 \& 986$, the court held that the defendant was guilty for misusing non-public price-sensitive information. See further Rider, Alexander, Linklater \& Bazley Market Abuse and Insider Dealing 60.

105 See similar remarks above.

106 See Chapter $X$ of the Financial Markets Act.

107 See related analysis above \& in paragraphs $2.1 ; 2.2$ \& 2.3 above.

108 See s 109(a) of the Financial Markets Act \& also see analysis by Chitimira \& Lawack 2013 Obiter 200-217; Chitimira 2014 Speculum Juris $108-124$.

109 This could probably fail to deter and prevent all persons especially companies or other entities from wilfully indulging in market abuse activities. S 109(a) of the Financial Markets Act.

110 See related remarks above.

111 S 84(2)(e).
} 
Markets Act. ${ }^{112}$

Detection and surveillance is another method employed by the enforcement authorities in South Africa to prevent market abuse practices. Thus, like the position in the UK where market abuse surveillance is extended to all the prescribed financial markets, ${ }^{113}$ such surveillance is also usually restricted to the regulated financial markets in South Africa. Moreover, as is the position with the FSA, ${ }^{114}$ the FSB uses the investigation and information gathering method to identify and prevent all possible contravention of market abuse provisions by both individuals and companies in South Africa. ${ }^{115}$ In line with this, as has already been said, ${ }^{116}$ in most instances the DMA may, on behalf of the FSB, summon, interrogate or search and seize documents or material from any person or premises when it objectively believes that such material or documents are relevant to the market abuse matter under investigation. ${ }^{117}$ However, the Financial Markets Act $^{118}$ do not expressly empower the FSB to appoint other additional competent persons apart from the members of the DMA to investigate the occurrence of market abuse activities in the South African financial markets. ${ }^{119}$

Awareness and educational programmes have further been employed by the FSB in an attempt to prevent market abuse practices in the South African financial markets. The FSB, for example, issues some quarterly informative market abuse booklets on its website to increase the general awareness among the market participants and all the relevant stakeholders. ${ }^{120}$ However, unlike the FSA which was statutorily obliged to publish a detailed Code of Market Conduct, ${ }^{121}$ the FSB is not expressly and statutorily empowered to provide a similar code of market conduct to increase market abuse awareness and promote a good anti-market abuse corporate ethics culture in South Africa. ${ }^{122}$

\section{Concluding Remarks}

As indicated earlier, ${ }^{123}$ the FSA has relatively managed to formulate high level methods and preventative measures, especially in relation to the enforcement of market abuse laws in order to obtain more settlements and prosecutions in market abuse cases in the UK. For instance, the UK's market abuse regime has a number of measures in place such as market abuse awareness programmes; appointing additional skilled investigators; technological surveillance mechanisms and about 2500 to 3000 competent persons who work for the FSA in order to enhance the enforcement of the market abuse provisions in the UK. ${ }^{124}$ On the other hand, relatively few anti-market abuse preventative measures have been adopted in South Africa. ${ }^{125}$ Consequently, South Africa has so far not been able to successfully and consistently enforce its market abuse prohibition, particularly in cross-border market abuse cases and over the counter markets. ${ }^{126}$ In relation to this, it is suggested that the Financial Markets Act should be amended to enact provisions that expressly empower other SROs in South Africa, apart from the FSB, to impose their own penalties or take any other appropriate action against any persons who indulge in market abuse activities in South Africa. ${ }^{127}$

It is also submitted that a significant number of flaws and challenges such as the adoption of few market abuse preventative measures and the failure to provide separate and distinct penalties for companies and individuals could also have marred the successful enforcement of the market abuse ban in South Africa to date. ${ }^{128}$ It is further submitted that the FSB should be expressly and statutorily authorised to impose separate and different penalties on individuals and juristic persons or companies that engage in market abuse activities in South Africa. It is also recommended that the Financial Markets Act should be reviewed to enact provisions that give private rights of action to the affected persons for them to claim their damages directly from the market abuse offenders. Moreover, it is recommended that the Financial Markets Act should be reviewed to introduce whistle-blower immunity provisions for the purposes of encouraging all the persons to voluntarily disclose any information regarding market abuse activities to the FSB or other enforcement authorities in South Africa.

\footnotetext{
$112 \mathrm{~S} 84(2)(e)$. It is generally believed that potential offenders might desist from committing market abuse offences if they are aware that their identity and illicit trading practices, if caught, will be made public.

${ }^{113}$ See generally related remarks in paragraph 2.2 above.

114 See earlier related remarks above.

115 S 84(2)(a) \& (b); (3) read with subsecs (4) \& (5) of the Financial Markets Act. Also see analysis by Chitimira \& Lawack 2013 Obiter $200-217$.

116 See further related remarks in paragraph 2.2 above; also see $s 85$ of the Financial Markets Act.

117 See $s 85$ read with $s 84$ of the Financial Markets Act.

${ }_{118}$ See $s 84$ of the Financial Markets Act.

119 See related analysis in paragraphs $2.1 \& 2.2$ above.

120 See similar comments above \& Chitimira \& Lawack 2013 Obiter 200-217.

121 See similar remarks above.

122 See Chapter X of the Financial Markets Act, which outlines market abuse offences in South Africa; also see related analysis by Chitimira \& Lawack 2013 Obiter $200-217$.

${ }_{123}$ See related analysis in paragraphs $2.1 ; 2.2 ; 2.3 \& 3$ above.

124 See related analysis in paragraphs $2.1 ; 2.2 ; 2.3$ \& 3 above

125 See related analysis in paragraphs $2.1 ; 2.2 ; 2.3 \& 3$ above.

${ }^{126}$ See related analysis in paragraphs $2.1 ; 2.2 ; 2.3 \& 3$ above.

127 This should, however, be carefully utilised and enforced to avoid other possible constitutional-related conflicts and/or double jeopardy.

128 See related remarks in paragraphs $1 ; 2.1 ; 2.2 ; 2.3$ \& 3 above.
} 
It is also suggested that the FSB should seriously consider establishing its own surveillance systems to improve and increase the timeous detection of market abuse activity in both the regulated and unregulated financial markets in South Africa. It is further submitted that the relevant provisions of the Financial Markets Act which now empower the FSB to assist foreign regulators with investigations pertaining to any cross-border market abuse cases should be effectively and consistently utilised to enhance the combating of such cases in South Africa and elsewhere. Furthermore, the FSB should enter into more co-operation arrangements with international regulatory bodies that enforce commodities-based market abuse laws such as the CFTC, the LIFFOEAM and the TPSE to increase the combating of commodities-based market abuse practices in South Africa.

The Financial Markets Act should be reviewed to enact provisions that expressly impose a mandatory co-operation obligation on both the FSB and the JSE to improve the enforcement of the market abuse prohibition in South Africa. Over and above, it is recommended that the FSB and the JSE should consider embarking more on awareness and educative programmes such as developing an adequate anti-market abuse curriculum to be taught to students from high school level up to tertiary level; publishing some quarterly informative market abuse booklets on their respective websites; conducting market abuse workshops and public lectures to prevent market abuse practices and increase the general awareness among the market participants and/or other relevant stakeholders in the South African financial markets.

In a nutshell, it is hoped that the recommendations as enumerated above will be utilised in the future to consistently discourage market abuse activity in both the UK and South African financial markets.

\section{References}

Avgouleas E The Mechanics and Regulation of Market Abuse: A legal and Economic Analysis (Oxford University Press Oxford 2005) Barnes P Stock Market Efficiency, Insider Dealing and Market Abuse (Gower Publishing Limited Surrey England 2009)

Beuthin RC and Luiz SM Beuthin's Basic Company Law $3^{\text {rd }}$ ed (Butterworths Durban 2000)

Blair MQC \& Walker GA (eds) Financial Services Law 1 ${ }^{\text {st }}$ ed (Oxford University Press Oxford United Kingdom 2006)

Lyon GJ \& Du Plessis JJ The Law of Insider Trading in Australia (The Federation Press Sydney 2005)

Rider B, Alexander K, Linklater L \& Bazley S Market Abuse and Insider Dealing $2^{\text {nd }}$ ed (Tottel Publishing Haywards Heath 2009)

Russen J Financial Services Authorisation, Supervision, and Enforcement: A Litigator's Guide (Oxford University Press New York 2006) Swan EJ Market Abuse Regulation $1^{\text {st }}$ ed (Oxford University Press United States of America 2006)

Wood PR Regulation of International Finance (The Law and Practice of International Finance Series Volume 7) $1^{\text {st }}$ ed (Sweet \& Maxwell Limited London 2007)

\section{Journal articles}

Bhattacharya U \& Daouk H "The World Price of Insider Trading" 2002 Journal of Finance 75-108

Black J \& Nobles R "Personal Pensions Misselling: The Causes and Lessons of Regulatory Failure" 1998 MLR 789-820

Botha D "Control of Insider Trading in South Africa: A Comparative Analysis" 1991 SA Merc LJ 1-18

Botha D "Increased Maximum Fine for Insider Trading: A Realistic and Effective Deterrent?" 1990 SALJ 504-508

Cassim R "An Analysis of Market Manipulation under the Securities Services Act 36 of 2004 (Part 1)" 2008 SA Merc LJ 33-60

Cassim R "An Analysis of Market Manipulation under the Securities Services Act 36 of 2004 (Part 2)" 2008 SA Merc LJ 177-199

Cassim R "Some Aspects of Insider Trading - Has the Securities Services Act, 36 of 2004 Gone too Far?" 2007 SA Merc LJ 44-70

Chitimira H \& Lawack VA "Overview of the Role-Players in the Investigation, Prevention and Enforcement of Market Abuse Provisions in South Africa" 2013 Obiter 200-217

Chitimira H "Overview of Selected Role-Players in the Detection and Enforcement of Market Abuse Cases and Appeals in South Africa" 2014 Speculum Juris 108-124

Henning JJ \& Du Toit S "The Regulation of False Trading, Market Manipulation and Insider Trading" 2000 Journal for Juridical Science $155-165$

Jooste R "A critique of the insider trading provisions of the 2004 Securities Services Act" 2006 SALJ 437-460

Kiernan P "The Regulatory Bodies Fraud: Its Enforcement in the Twenty-First Century" 2003 The Company Lawyer 293-299

Luiz SM "Market Abuse and the Enforcement Committee" 2011 SA Merc LJ 151-172

Luiz SM "Insider Trading Regulation - If at First You Don't Succeed..." 1999 SA Merc LJ 136-151

Osode PC "The new South African Insider Trading Act: Sound law reform or legislative overkill?" 2000 Journal of African Law 239-263

Rider BAK "Policing the City-Combating Fraud and Other Abuses in the Corporate Securities Industry" 1988 Current Legal Problems 4768

Steinberg MI "Insider Trading Regulation-A Comparative Perspective" 2003 The International Lawyer 153-171

Van Deventer G "New watchdog for insider trading" 1999 FSB Bulletin 2-3

Van Deventer G "Harnassing Administrative Law in Encouraging Compliance" 2009 FSB Bulletin 3-4 


\section{Case Law}

South Africa

Pretorius and Another v Natal South Sea Investment Trust 19653 SA 410 (W)

United Kingdom

Bell v Lever Brothers Ltd [1932] AC 161

Chase Manhattan Equities v Goodman [1991] BCLC 897

Chaston v SWP Group Ltd [2003] 4 Current Law 78

El Ajovu v Dollar Holdings [1993] 1 BCLC 760

Financial Services Authority v Fitt [2004] EWHC 1669 ch

Financial Services Authority v Martin and Anor [2005] 1 BCLC 495

Financial Services Authority v (1) Sean Fradley (t/a Top Bet Placement Services) (2) Gary Woodward [2004] EWHC 3008 (Ch)

In Re A-G's Reference (No 1 of 1998) [1998] BCLC 193

In Re A-G's Reference (No 1 of 1988) [1989] AC 971

Legal and General Assurance Society Limited v Financial Services Authority (2005) FSMT 016

Mohammed v FSA (2005) 013

Philip Jabre v Financial Services Authority (2006) 36 fin 06/2006

Piggott v FSA (2003) FSMT 004

$R$ v Caldwell [1982] AC 341

R v Ghosh [1982] QB 1053

R v Kylsant [1932] 1 KB 442

R (on the application of Davies and others) v Financial Services Authority [2003] 4 All ER 1196

R v Rigby, Bailey \& Rowley (2005) FSA/PN/106/2005 2005-10-07

Scott v Brown [1892] QB 724

Seager v Copydex (No 2) [1969] 1 WLR 809

SIB v Pantell SA (No 2) [1993] BCLC 146 (CA)

\section{Legislation}

\section{South Africa}

Companies Act 61 of 1973

Companies Act 71 of 2008

Consumer Protection Act 68 of 2008

Financial Institutions (Protection of Funds) Act 28 of 2001

Financial Markets Act 19 of 2012

Financial Markets Control Act 55 of 1989

Securities Services Act 36 of 2004

Stock Exchanges Control Act 1 of 1985

United Kingdom

Companies Act 1980 (c 22)

Companies Act 1985 (c 6)

Companies Act 2006 (c 46)

Company Securities (Insider Dealing) Act 1985 (c 8)

Criminal Justice Act 1993 (c 36)

Criminal Justice Act 1987 (c 38)

Financial Services and Markets Act 2000 (c 8)

Financial Services Act 1986 (c 60)

Fraud Act 2006 (c 35)

Larceny Act 1861 (24 and 25 Vict c 96)

Powers of Criminal Courts (Sentencing) Act 2000 (c 6)

Prevention of Fraud (Investments) Act 1939 (c 16)

Prevention of Fraud (Investments) Act 1958 (c 45)

Supreme Court Act 1981 (c 54) 


\section{European Union}

Commission Directive 2003/124/EC of 22 December 2003 implementing Directive 2003/6/EC of 28 January 2003 on the definition and public disclosure of inside information and the definition of market manipulation [2003] OJ L339/70

Commission Directive 2003/125/EC of 22 December 2003 on the fair presentation of investment recommendations and the disclosure of conflicts of interest [2003] OJ L339/073

European Union Directive on Insider Dealing and Market Manipulation, the Directive of the European Parliament and Council of 28 January 2003 on insider dealing and market manipulation (market abuse) 2003/6/EC [2003] OJ L96/16

European Union Insider Dealing Directive, Council Directive 89/592/EEC of 13 November 1989 [1989] OJ 1989 L334/30

\section{Commissions, Committees, Statutory Instruments and Reports}

\section{South Africa}

Financial Services Board Annual Report 2011

Financial Services Board Annual Report 2013

The King Task Group into Insider Trading Legislation Minority Report on Insider Trading 1997

The King Task Group into the Insider Trading Legislation First Report 15 May 1997

The King Task Group into the Insider Trading Legislation Final Report 21 October 1997

Van Wyk de Vries Commission of Inquiry into the Companies Act of 1973

\section{United Kingdom}

Enforcement (Settlement and Other Procedures) Instrument's Decision Making Manual October 2005

Financial Services and Markets Act 2000 (Market Abuse) Regulations 2005 SI 2005/381

Financial Services and Markets Act 2000 (Prescribed Markets and Qualifying Investments) Order 2001, SI 2001/1996 as amended by Regulation 10 of the Market Abuse Regulations 2005

Financial Services Authority Handbook (Code of Market Conduct) FSA Release 19 July 2001

Financial Services Authority's Market Abuse Directive Disclosure Rules Instrument 2005, 17 March 2005

Financial Services Authority's Market Abuse Directive Instrument 2005, 17 March 2005

Insider Dealing (Securities and Regulated Markets) Order 1994

Traded Securities (Disclosure) Regulation 1994

\section{Thesis and Dissertations}

Chitimira H A Comparative Analysis of the Enforcement of Market Abuse Provisions (LLD-thesis Nelson Mandela Metropolitan University 2012)

Chitimira H The Regulation of Insider Trading in South Africa: A Roadmap for an Effective, Competitive and Adequate Regulatory Statutory Framework (LLM-dissertation University of Fort Hare 2008)

\section{Newspaper Reports}

Chanetsa B "Insider Trading is Notoriously Hard to Prosecute" Business Report 26 April 2004

\section{Internet Sources}

Barron C "Greg Draws a Blank in Belfort Parallel" (2014) <http://www.timeslive.co.za/Feeds/2014/02/02/greg-draws-a-blank-in-belfortparallel> (accessed 03-03-2014)

Blincoe R "Datatec Directors Pay Up on Insider Trading Charges" (2001) <http://www.theregister.co.uk/2001/05/23/datatec_ directors_pay_up/> (accessed 03-03-2014)

Commodity Futures Trading Commission \& the Financial Services Authority FSA's Memorandum of Understanding on Consultation, Cooperation and the Exchange of Information Related to Market Oversight (2006) <http://www.fsa.gov.uk/pubs/mou/cttc.pd> (accessed 27-01-2014)

Financial Services Authority "FSA Signs Regulatory Cooperation Agreement with the CFTC" (20-11-2006) http://www.fsa.gov.uk/pages/ Library/Communication/PR/2006/118.shtml> (accessed 27-01-2014)

Financial Services Board "Enforcement Committee Actions" Media Release (28-06-2011) <http://www.fsb.co.za/ftp://ftp.fsb.co.za/ public/documents/AReport2011.pdf> (accessed 22-11-2013)

Financial Services Board "List of Current Investigations of the Directorate of Market Abuse" Media Release (28-06-2011) <http://www.fsb.co.za/ftp://ftp.fsb.co.za/public/documents/AReport2011.pdf> (accessed 22-11-2013) 
Johannesburg Stock Exchange Limited "Insider Trading and other Market Abuses (Including the Effective Management of PriceSensitive Information)" in the Insider Trading Booklet, (2013) <http://www.jse.co.za/Libraries/JSE_ Regulatory_Environment_ Insider_Trading/InsiderTrading_Booklet.sflb.ashx> (accessed 03-03-2014)

Loubser "Insider Trading and other Market Abuses (Including the Effective Management of Price-sensitive Information)" in the Insider Trading Booklet final draft, (2006) <http://www.jse.co.za/public/insider/JSEbooklet.pdf> (accessed 03-03-2014)

Myburgh A \& Davis B "The Impact of South Africa's Insider Trading Regime: A Report for the Financial Services Board" (25-03-2004) $<$ http://www.genesis-analytics.com/public/FSBReport.pdf> (accessed 09-02-2013)

Van Deventer G "Anti-Market Abuse Legislation in South Africa" (10-06-2008) <http://www.fsb.co.za/public/marketabuse/FSBReport.pdf> (accessed 05-05-2013) 